
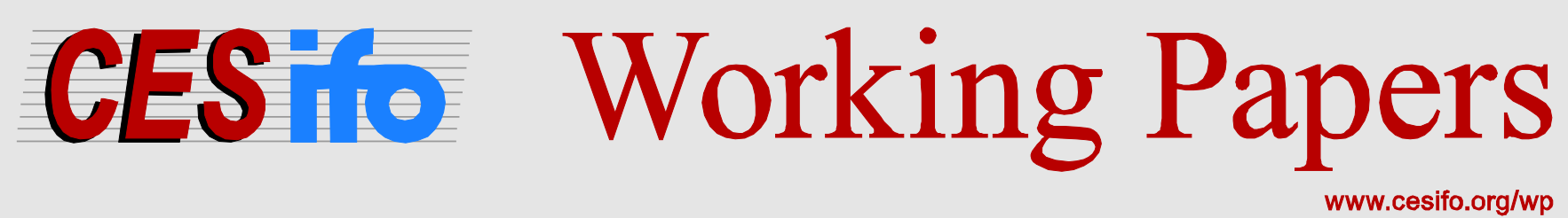

\title{
Wages and Recruitment: Evidence from External Wage Changes
}

\author{
Torberg Falch
}

CESIFO WORKING PAPER NO. 4078

CATEGORY 4: LABOUR MARKETS

JANUARY 2013

An electronic version of the paper may be downloaded

- from the SSRN website:

- from the RePEc website:

WwW.SSRN.com

- from the CESifo website:

www.RePEc.org

www.CESifo-group.org/wp

\section{CESifo}




\title{
Wages and Recruitment: Evidence from External Wage Changes
}

\begin{abstract}
This paper estimates the causal effect of the wage on the recruitment rate at the establishment level. During the 1990s, the wage setting for certified teachers in Norway was completely centralized, with a wage premium of about 10 percent at schools with severe recruitment problems in the past and located in one specific region. The empirical approach exploits within-school variation in wage premium eligibility and that teacher supply is observed at these schools with excess demand for teachers. In a difference-in-differences framework, I find that the wage premium increased the recruitment rate by 6-7 percentage points. The finding is robust to model specification and sample, but larger for young teachers than old teachers. The results indicate that the short-run labor supply elasticity towards the individual establishment is about 1.4.
\end{abstract}

JEL-Code: J220, J450.

Keywords: recruitment, wages, labor supply, teacher mobility.

\author{
Torberg Falch \\ Department of Economics \\ Norwegian University of Science and Technology \\ Dragvoll \\ 7491 Trondheim \\ Norway \\ Torberg.Falch@svt.ntnu.no
}

Comments from Bjarne Strøm, Julie Cullen, Oline Ervik, Helen Ladd, Alan Manning, Todd Sorensen, seminar participants at University of Amsterdam, University of ErlangenNuremberg, and Norwegian University of Science and Technology, and conference participants at The International Institute of Public Finance and the annual meeting of the Norwegian Economic Association on an earlier version of this paper are greatly acknowledged. 


\section{Introduction}

Most empirical papers in labor economics have a neoclassical foundation. Recently it has been increasingly recognized that labor markets are imperfectly competitive. Employers have hiring costs and workers have searching costs, and consequently there are rents in employment relationships.

While the theoretical literature on search and matching mainly models the recruitment process, ${ }^{1}$ the micro-econometric literature on wage responses are almost exclusively on separations. ${ }^{2}$ The empirical literature on recruitment and wages seems to include only Krueger (1988), Holzer et al. (1991) and Bó et al. (2012). These papers estimate how the number of job applicants is related to the wage. In addition, the experiment with exogenous wage variation for some new public sector positions in Mexico exploited by Bó et al. allows for analyzing wage effects on the qualification of the application pool and on the acceptance rate of job offers.

The present paper analyzes a labor market with shortages of qualified labor. Wage determination for Norwegian teachers was completely centralized in the 1990s, but some schools in a specific region were in some years eligible for a wage premium paid by the state. Wage premium eligibility was determined by previous shortages of certified teachers. Given teacher shortages, the present paper estimates the wage effect on recruitment in a difference-in-differences framework.

Recruitments and separations are related to changes in labor supply at the establishment level. Manning (2003, 2011) shows that when averaging across the economy in steady state, separation and recruitment elasticities to the wage are identical in absolute terms. A separation is recruitment in another firm. The elasticity of labor supply can thus be inferred by the separation elasticity alone, which has been done in several studies. ${ }^{3}$ However, the reasoning on a steady state economy is not entirely satisfying since the

\footnotetext{
${ }^{1}$ See for example Rogerson et al. (2005) for a the survey of the literature. Brown et al. (2012) expand the matching function to distinguish between the contact stage and the selection stage.

${ }^{2}$ See for example Manning (2011) for a survey of the literature.

${ }^{3}$ Studies calculating the labor supply elasticity based on separation elasticities include Depew and Sorensen (2012), Falch (2011), Hirsch et al. (2010), Hotchkiss and Quispe-Agnoli (2012), Manning (2003), Ransom and Oaxaca (2010), and Ransom and Sims (2010).
} 
idea of imperfect competition is based on firms having idiosyncratic components. Credible separation elasticities are estimated on specific labor markets, for which the Manning assumption does not hold. Teachers might take non-teaching jobs, engineers might take non-technology jobs, etc., which implies that a separation in a specific labor market often does not end up as a recruitment in a firm in the same labor market. In the present paper I show the majority of newly appointed teachers did not teach the previous school year. Thus, it is an empirical question whether the recruitment elasticity is equal to the separation elasticity in specific labor markets. I compare the estimated recruitment elasticity to the quit elasticity in Falch (2011), exploring the same experiment. ${ }^{4}$

One argument for empirically analyzing separations in the labor market instead of recruitment is that separations are less affected by employer behavior. In the recruitment process, employers have in general other policy instruments in addition to the wage. A wage raise can be combined with reduced hiring costs. In the specific labor market studied in the present paper, hiring costs are arguably smaller and more fixed than in most labor markets, and I will provide some evidence that potential endogenous hiring costs do not seem to bias the wage estimate.

\section{The quasi-natural experiment}

The wage premium experiment took place in Norwegian compulsory public schools (first to tenth grade). Appointment rules for teachers are determined by general labor market regulations, the school act, and centralized bargaining with the teacher union (Bonesrønning et al., 2005). Teachers are employed by the school district, but the district cannot move a teacher to another school without a major downsizing of the school or an explicit approval by the particular teacher. The teachers are linked to the schools and not to the school districts, and can freely move to another school if a better locational opportunity comes up. An individual who is not certified as a teacher can only be employed if no certified teacher applies for a vacant teacher position, and noncertified teachers can only be hired for up to one school year. The subsequent year, the school has to make the vacant position public again and to search for certified

\footnotetext{
${ }^{4}$ Falch (2011) estimates the quit behavior of teachers in permanent positions. The same experiment is analyzed in a static framework in Falch (2010), using school level data for a short time period.
} 
teachers. Representatives of the teacher union take part in every hiring decision. In this way the union is able to closely monitor that the schools behave in accordance with the law, which has been one of the cornerstones in the teacher trade union policy. These institutions imply that observed teacher shortages in terms of employment of noncertified teachers reflect the state of the local teacher labor market the particular year.

The wage of an individual teacher was until 2001 solely determined by central wage bargaining. ${ }^{5}$ The wage varied across teachers only with respect to education level and teaching experience, but with one exception: Certified teachers in at least $50 \%$ appointment in schools with particular recruitment problems and located in one of the three northernmost counties (out of a total of 19 counties) were eligible for a wage premium of about $10 \%$ paid by the state. ${ }^{6}$ The school districts had no influence on school eligibility, and eligibility had no financial implications for them.

The experiment includes several schools during the school years 1993-94 to 2002-03. In 1993-94 to 1995-96, teachers in schools with more than $20 \%$ teacher shortages the previous school year were eligible for the wage premium. ${ }^{7}$ Teacher shortages are defined as the share of noncertified teacher man-years. Because the criterion for a higher wage was previous teacher shortages, it was known well in advance of the school year which schools would be eligible for a higher wage.

\footnotetext{
${ }^{5}$ Some limited local wage flexibility was introduced in the fall 2001, and the wage setting was further decentralized from 2004. Centrally allocated funds to be used for wage increases for a limited number of teachers became available for the school districts in 2001. The funds may have been used to increase the wage in the schools with the lowest supply. On the other hand, it also became possible to pursue a strategic policy in which wage increases were not allocated to schools that could be eligible for the wage premium since the wage premium was paid by the central government. Thus, the present paper only uses data for the period without local discretion.

${ }^{6}$ The wage premium was a fixed nominal amount independent of education and experience. The size of the premium changed in 1994 and 1998. The average percentage wage premium was lowest in 1993-94 (about $7.5 \%$ ) and highest in 1998-99 (about $12.0 \%$ ).

${ }^{7}$ For schools with 20-30 \% teacher shortages in the previous school year, the rules in 1993-94 to 1995-96 differed across school districts. In schools located in one of the north-east school districts, the teacher wage premium was about $10 \%$ when the shortages the previous year exceeded $30 \%$, but only about $5 \%$ with shortages in the range $20-30 \%$. In the other school districts, the wage premium was about $10 \%$ in all eligible schools.
} 
The eligibility criterion became stricter for the school years 1996-97 to 1997-98. Only teachers in schools with more than $30 \%$ teacher shortages in the previous school year received the higher wage. Within the last system, continuing to the school year 2002-03, teachers in schools with more than $20 \%$ teacher shortages on average during the four last school years got a wage premium, and the wage premium was equal across all included schools. Falch (2010) includes a more in depth description of the system.

Since a wage premium is expected to increase teacher supply, schools with teacher shortages marginally above the criterion for wage premium most likely increase the employment of teachers such that the school is not eligible for the wage premium the next school year. If the school loose eligibility, the incumbent teachers at the school kept their wage premium as long as the system was in place, while new hires did not.

Several of the treatment schools switched between paying wage premium and not during the empirical period. One system-induced explanation is that the eligibility criterion varied.

It has always been known in advance whether a school was eligible for the wage premium or not. The classification of schools was done by the relevant county governor's office. The county governor is appointed by the state and has mainly inspection duties related to all local public services. From 1998-99 it has been explicit in the instructions from the central government that schools eligible for wage premium next school year should be informed before March 1. For new positions made public before this date, the school districts had to pay the wage premium without compensation from the state.

Since wage premium eligibility is based on lagged information, it is in principle possible to game the system. If, for example, a school replaces quitting teachers with noncertified teachers, even though there are certified teachers interested in the positions, the incumbent teachers might get a wage premium the next school year. There are several reasons why such gaming of the system arguably did not occur. When I collected the data, the county governor offices reported they did not believe the system 
was manipulated. The appointment rules presented above are crucial in this regard. In addition, the criterion for wage premium varied over time, as described above, but the changes in the criterion has always been decided after the registration of teacher shortages. Both the changes in the system in 1996 and 1998 were decided in December the previous year, while the criterion is based on teacher shortages earlier in the fall. Finally, the last system from 1998 and onwards was even harder to manipulate since the criterion was based on four year averages.

\section{Data}

The treatment schools are located in the three northernmost counties in Norway, consisting of 90 school districts. ${ }^{8}$ The population is relatively scattered and relatively few workers reside in a school district other than the one that they work in. Information about the wage premium is provided by state representatives in the relevant counties.

Table 1 presents the number of schools and teachers with wage premium in the different school years. Few schools were eligible for a higher wage during the relatively restrictive system in 1996-97 and 1997-98, while about three times as many schools had wage premium in the preceding and following school years. Changes in the criterion over time imply that most schools only had a wage premium for a short period. Table 2 shows that out of the 158 treatment schools, new hires received wage premium in only one year in 66 of the schools. In 37 schools new hires received wage premium in more than 3 years. Due to school mergers and closures, the table is not symmetric.

Table 1. The number of schools and teachers with wage premium

\begin{tabular}{lcccccccc}
\hline & $1993-94$ & $1994-95$ & $1995-96$ & $1996-97$ & $1997-98$ & $1998-99$ & $1999-2000$ & $2000-01$ \\
\hline Schools & 69 & 45 & 33 & 22 & 16 & 62 & 72 & 72 \\
Teachers & 405 & 223 & 163 & 66 & 51 & 297 & 362 & 325 \\
\hline
\end{tabular}

Note: School and teacher observations in which only incumbent teachers are eligible for the wage premium are not included.

\footnotetext{
${ }^{8}$ Only public schools were eligible for the wage premium. However, only about $0.5 \%$ of the students in the relevant counties were enrolled at private schools.
} 
Individual teacher data with school identifier are provided by Statistics Norway. The estimation sample is restricted to certified teachers in at least $50 \%$ position since noncertified teachers and teachers with a shorter working day were not eligible for the wage premium. ${ }^{9}$ For the relevant counties, the average share of teachers in the empirical period who get a wage premium is shown in Figure 1. School districts in which teachers have received the wage premium are spread all over the region, although the wage premium is most common in the northernmost county. $77 \%$ of the school districts include at least one treatment school in the empirical period, while $13 \%$ have an average share of teachers who got a wage premium above $15 \%$.

Table 2. Years with wage premium for the treatment schools

\begin{tabular}{lcccccccccc}
\hline & 0 years & 1 year & 2 years & 3 years & 4 years & 5 years & 6 years & 7 years 8 years & Sum \\
\hline $\begin{array}{l}\text { Wage premium to all } \\
\text { teachers }\end{array}$ & 0 & 66 & 34 & 22 & 12 & 12 & 5 & 3 & 4 & 158 \\
$\begin{array}{l}\text { Not wage premium for } \\
\text { new hires }\end{array}$ & 8 & 8 & 7 & 15 & 13 & 22 & 30 & 55 & 0 & 158 \\
\hline
\end{tabular}

Figure 1. The average extent of wage premium at the teacher level

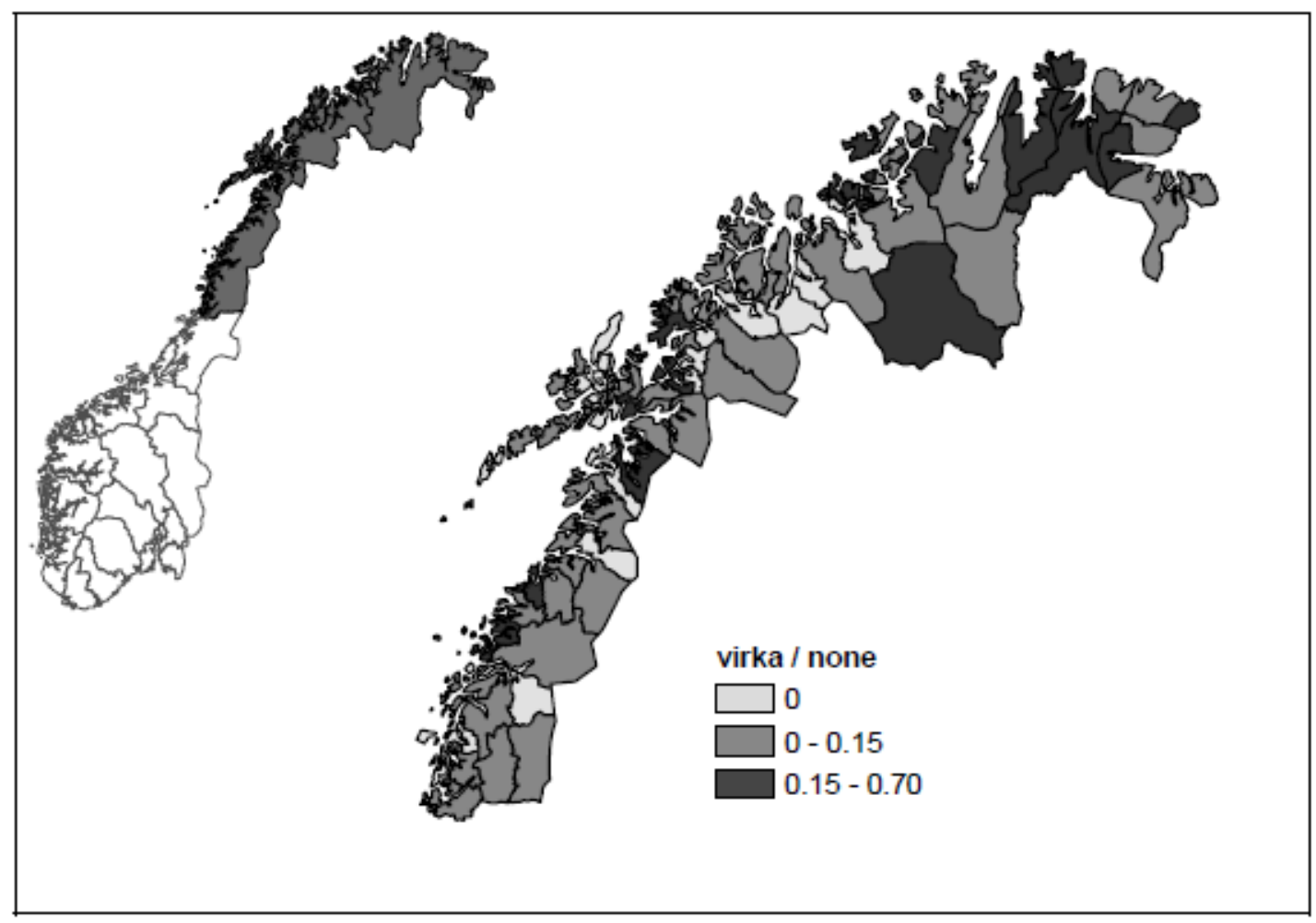

\footnotetext{
${ }^{9}$ The share of non-eligible teachers is $11.4 \%$ in the original data. The first year of new schools in the data is also excluded from the analysis since then all teachers are new hires ( $0.5 \%$ of the observations).
} 
Descriptive statistics are presented in Table 3. The data consists of 79,135 teachers, of whom 10,868 have been working in one of the counties with treatment schools, and 2,034 have been working at a treatment school during the empirical period. On average, $15.5 \%$ of the certified teachers are new hires. The recruitment rate is about the same in the relevant counties, but clearly higher in the schools. With the wage premium, the average recruitment rate is $25.4 \%$, while without wage premium in the treatment schools the recruitment rate is $19.7 \%$. The difference of 5.7 percentage points (pp) is significant at conventional levels. Figure 2 takes unobservables into account. The figure presents the density of the change in the average recruitment rate at the school level when a wage premium is introduced and removed. The mean values are 2.9 and $-8.7 \mathrm{pp}$, respectively, which imply a difference-in-differences parameter of $5.8 \mathrm{pp}$.

Table 3 also presents descriptive statistics for some teacher characteristics. Both the average age, the share of female teachers, the share of married teachers, and the share of teachers with a permanent teacher position last year are lower in the treatment schools than in other schools. In addition, the schools in the relevant counties are smaller than in the rest of the country, which is in particular the case for the treatment schools.

Panel B of Table 3 presents descriptive statistics for the observations of recently hired teachers. Compared to all teachers in Panel A, they are younger, they are to a lesser extent married, and fewer had a permanent teacher position last school year. The characteristics of the recently hired teachers are not significantly related to the wage premium. 
Table 3. Descriptive statistics, mean values (standard deviation)

\begin{tabular}{|c|c|c|c|c|c|}
\hline & \multirow[b]{2}{*}{ All schools } & \multirow{2}{*}{$\begin{array}{l}\text { Schools in } \\
\text { the relevant } \\
\text { counties }\end{array}$} & \multicolumn{3}{|c|}{ Treatment schools } \\
\hline & & & $\begin{array}{l}\text { Wage premium } \\
\text { for new hires }\end{array}$ & $\begin{array}{l}\text { Without wage } \\
\text { premium for new } \\
\text { hires }\end{array}$ & Difference \\
\hline \multicolumn{6}{|l|}{ Panel A: All teachers } \\
\hline Recently hired teachers & 0.155 & 0.159 & 0.254 & 0.197 & $0.057 *(0.011)$ \\
\hline Age & $44.3[10.3]$ & $43.1[10.2]$ & $40.0[10.7]$ & $40.8[10.4]$ & $-0.766 *(0.283)$ \\
\hline Women & 0.663 & 0.623 & 0.613 & 0.616 & $-0.003(0.013)$ \\
\hline Children 6-18 years of age & 0.409 & 0.429 & 0.398 & 0.418 & $-0.020(0.013)$ \\
\hline Married & 0.696 & 0.637 & 0.522 & 0.559 & $-0.037 *(0.013)$ \\
\hline Permanent teacher position last year & 0.790 & 0.786 & 0.730 & 0.684 & $-0.046 *(0.012)$ \\
\hline Number of students & $245[134]$ & 191 [132] & $58.7[57.9]$ & $68.4[53.1]$ & $-9.64 *(1.47)$ \\
\hline Observations & 401,483 & 51,313 & 1,892 & 5,073 & 6,965 \\
\hline Number of teachers & 79,135 & 10,868 & 1,202 & 1,714 & 2,034 \\
\hline Number of schools & 3.313 & 567 & 158 & 150 & 158 \\
\hline \multicolumn{6}{|l|}{ Panel B: Recently hired teachers } \\
\hline Age & $36.0[10.1]$ & $35.6[9.80]$ & 34.6 [10.2] & $34.9[9.90]$ & $-0.334(0.555)$ \\
\hline Women & 0.719 & 0.658 & 0.605 & 0.622 & $-0.017(0.027)$ \\
\hline Children 6-18 years of age & 0.341 & 0.338 & 0.268 & 0.305 & $-0.037(0.025)$ \\
\hline Married & 0.495 & 0.409 & 0.310 & 0.353 & $-0.043(0.026)$ \\
\hline Permanent teacher position last year & 0.229 & 0.224 & 0.212 & 0.182 & $0.030(0.022)$ \\
\hline Number of students & $245[141]$ & $180[134]$ & $50.0[54.6]$ & $65.3[51.9]$ & $-15.3^{*}(2.93)$ \\
\hline Observations & 62,319 & 8,180 & 481 & 1,000 & 1,481 \\
\hline Number of teachers & 45,188 & 6,198 & 470 & 942 & 1,343 \\
\hline Number of schools & 3.258 & 546 & 129 & 135 & 153 \\
\hline
\end{tabular}

Note. Mean values, standard deviations in brackets, and standard errors in parentheses. ${ }^{*}$ denotes significance at $5 \%$ level. 
Figure 2. Kernel densities for changes in recruitment ratio at the school level

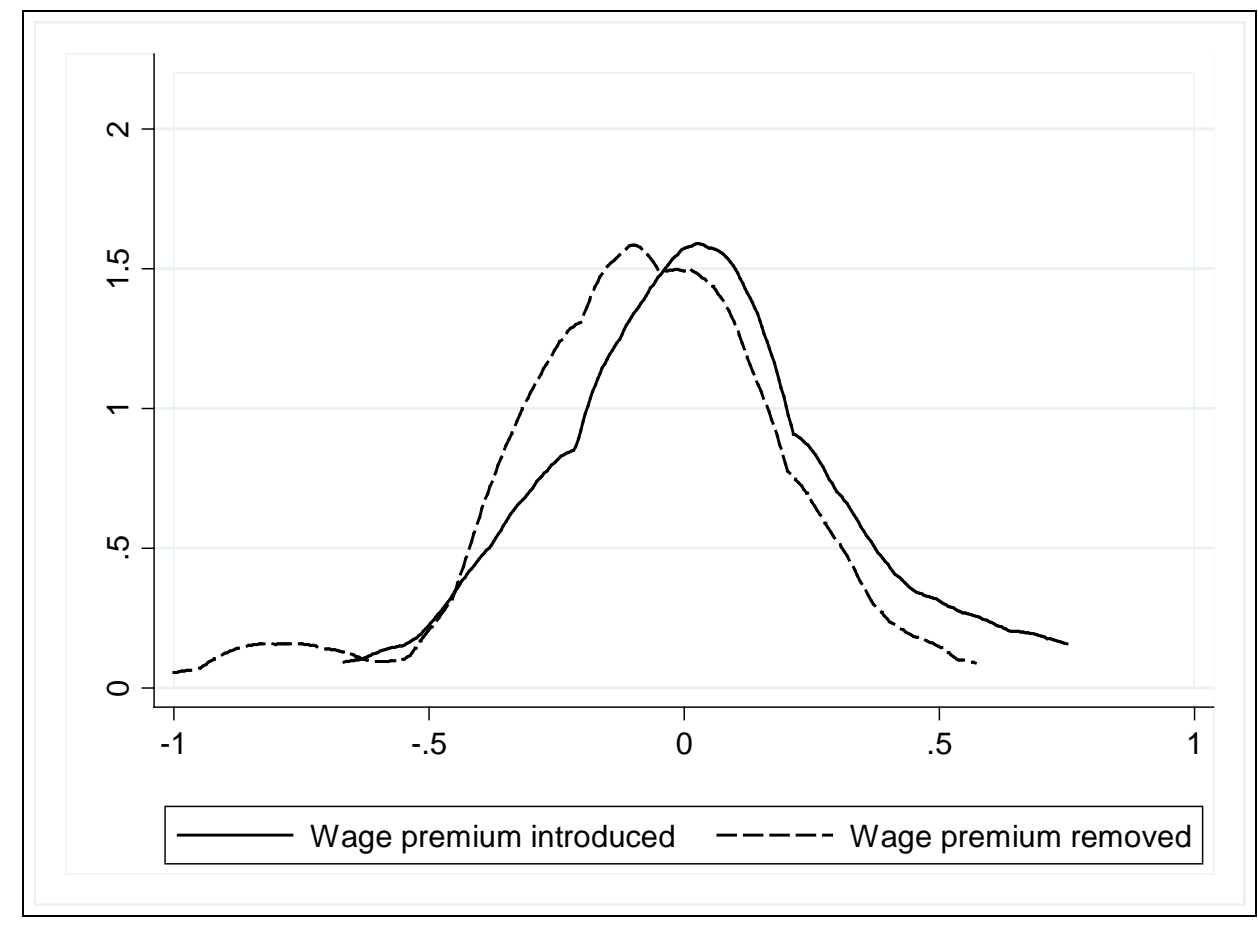

Table 4 gives some information about new hires’ previous positions. On average for all schools, $9.9 \%$ of the teachers did not work in compulsory education or in upper secondary education the previous school year. This number includes novice teachers in their first job. The recruitment pattern for the schools in the relevant counties is almost exactly the same as in the rest of the country. Interestingly, the share of teachers from all origins is larger when treatment schools pay wage premium compared to when they do not. The difference is significant at $5 \%$ level for the origins "did not teach last year", "worked at another school last year, with wage premium, in the same school district", and "worked at another school last year, without wage premium, in another school district”. Thus, the larger recruitment rate with wage premium does not reflect larger recruitment from specific origins. 
Table 4. The origin of the teachers, percent

\begin{tabular}{|c|c|c|c|c|c|}
\hline & \multirow[b]{2}{*}{$\begin{array}{c}\text { All } \\
\text { schools }\end{array}$} & \multirow{2}{*}{$\begin{array}{l}\text { Schools } \\
\text { in the } \\
\text { relevant } \\
\text { counties }\end{array}$} & \multicolumn{3}{|c|}{ Treatment schools } \\
\hline & & & $\begin{array}{c}\text { Wage } \\
\text { premium for } \\
\text { new hires }\end{array}$ & $\begin{array}{l}\text { Without wage } \\
\text { premium for } \\
\text { new hires }\end{array}$ & Difference \\
\hline Incumbent & 84.5 & 84.1 & 74.6 & 80.3 & $-5.71 *(1.10)$ \\
\hline Did not teach last year & 9.89 & 10.1 & 17.0 & 13.7 & $3.27 *(0.95)$ \\
\hline $\begin{array}{l}\text { Worked at another school last year } \\
\text { with wage premium, in the same school district }\end{array}$ & 0.02 & 0.17 & 0.79 & 0.20 & $0.60 *(0.16)$ \\
\hline with wage premium, in another school district & 0.05 & 0.19 & 0.37 & 0.24 & $0.13(0.14)$ \\
\hline without wage premium, in the same school district & 3.14 & 3.19 & 2.96 & 2.66 & $0.30(0.44)$ \\
\hline without wage premium, in another school district & 2.42 & 2.35 & 4.33 & 2.92 & $1.42 *(0.48)$ \\
\hline Observations & 401,483 & 51,313 & 1,892 & 5,073 & 6,965 \\
\hline
\end{tabular}

Note. Standard errors in parentheses, * denotes significance at $5 \%$ level.

\section{Empirical strategy}

I relate the probability that a teacher is recently hired to the wage premium and estimate variations of the following model. ${ }^{10}$

$\mathrm{r}_{\mathrm{ijt}}=\gamma \mathrm{W}_{\mathrm{jt}}+\phi_{1} \mathrm{~S}_{\mathrm{jt}}+\phi_{2} \mathrm{X}_{\mathrm{ijt}}+\alpha_{\mathrm{j}}+\alpha_{\mathrm{t}} * \alpha_{\mathrm{d}}+\beta_{\mathrm{t}} * \mathrm{~T}_{\mathrm{j}}+\beta_{\mathrm{j}} * \mathrm{t}+\varepsilon_{\mathrm{ijt}}$,

where $r_{j t}^{i}$ is a dummy variable for whether teacher $i$ at school $j$ is recruited in year $t . W$ is an indicator for wage premium, $\mathrm{S}$ and $\mathrm{X}$ are school and individual characteristics, respectively, $\alpha_{\mathrm{j}}, \alpha_{\mathrm{t}}$, and $\alpha_{\mathrm{d}}$ are school, year, and school district specific effects, respectively, $\mathrm{T}$ is an indicator for treatment school, and $\varepsilon$ is the error term. $\gamma$ is the parameter of interest. The inclusion of school fixed effects implies that the model amounts to a difference-in-differences specification. Controlling for time is important since, e.g., the extent of wage premium varies across the years. The interaction between year fixed effects and school district fixed effects captures all common yearly elements

\footnotetext{
${ }^{10}$ Separation and recruitment decisions are in general not separable. However, analyzing the matching process of teachers and schools is complicated by the fact that one only observes actual matches and not all potential matches. To estimate a structural model including both quit and matching decisions, one needs information on the searching behavior of teachers. Boyd et al. (2012) estimate a matching model for the initial sorting of newly educated teachers to different schools. By focusing on the initial matching they reduce the number of potential matches and avoid modeling quit decisions. For the present paper the whole labor market for certified teachers is relevant. Then each individual with a teacher certificate, employed at a school or not, is relevant for vacant teacher posts.
} 
in the teachers' choice set at the school district level. In addition, the model allows for different time trends in treatment schools and other schools, modeled flexibly as the interaction between year fixed effects $\left(\beta_{t}\right)$ and the indicator for treatment school. Finally, the model include school specific time trends $\left(\beta_{\mathrm{j}}{ }^{*} \mathrm{t}\right)$. Standard errors will be clustered by school.

Whether individual characteristics should be included in the model is not obvious. From the point of view of labor supply elasticity faced by the establishment, the interesting question is how a higher wage will affect the number applicants, without regard to characteristics of these applicants. One would expect that new applicants have characteristics which in general make them mobile, such as young and without current permanent position. A conditional model will estimate the wage effect on the "average" worker. The wage response is therefore expected to be smaller in models including individual characteristics than in models without individual characteristics, but less informative about the labor supply to the school. The analysis below firstly presents models without individual characteristics, and subsequently adds observable and unobservable teacher characteristics.

There are four concerns by estimating (1) that will be addressed in the analyses. First, several of the control schools might be very different from the treatment schools, partly because they are located in other parts of the country and partly because the treatment schools tend to be small. I estimate the model on several different samples. The estimated wage effect turns out to be insensitive to sample, probably because the main identifying variation is within the treatment schools. Second, truncation might be an issue since some school observations actually do not have excess demand. One cannot rule out that there are teachers interested in working at such schools without getting a job offer, i.e., one observes demand and not supply. If the wage has a strong effect on teachers' mobility decisions, one would expect the wage premium to be positively related to absence of excess demand. In this case, the estimated effect of the wage premium will be downward biased. The relevance of the truncation issue will be investigated estimating models restricting the sample to schools with vacant teacher positions. 
Third, a negative shock in supply might make the school eligible for the wage premium, and with mean reversion in the data the estimated effect of the wage premium will be upward biased. To investigate the relevance of mean reversion, models that condition on previous teacher shortages in various ways are estimated. I also perform a falsification test by utilizing that wage premium eligibility was restricted to only some counties. Finally, according to Manning's (2003, 2011) model, the optimal behavior of firms faced by increased wage is to reduce recruitment effort. In that case, the estimate will be a combined effect of the wage premium and reduced recruitment costs, yielding a smaller estimate than the pure wage effect. In the specific labor market studied in the present paper, hiring costs are arguably smaller and more fixed than in most labor markets. All vacant positions have to be made public in specific magazines, and potential teachers know where to find the information. If the schools and the school districts change recruitment effort strategically, one would, however, expect that the optimal behavior also depends on other circumstances. I investigate whether the wage effect depends on the degree of teacher shortages the previous school year and on the change in the number of students.

\section{Empirical results}

The first column in Table 5 shows that the correlation between recruitment and the wage premium is relatively large. The probability of being recently hired is 9.8 percentage points (pp) higher when there is a wage premium. ${ }^{11}$ Column (2) includes two sets of year specific effects, one set for the treatment schools and another set for the control schools. Then the correlation is reduced to $7.3 \mathrm{pp}$.

The main identification in this paper is based on within-school variation. Results for the most simple difference-in-differences specification are presented in column (3) in Table 5, with an effect of $6.5 \mathrm{pp}$. Including year times school district fixed effects to control for conditions in the choice set of teachers (column 4) does not alter the wage effect, while including school specific trends (column 5) increases the estimate to $7.0 \mathrm{pp}$.

\footnotetext{
${ }^{11}$ The estimated effect is larger than the difference in Table 3 because the regression model includes all observations of teachers in Norway, not just observations for treatment schools.
} 
Overall, the wage effect is $30-33 \%$ of the recruitment ratio. ${ }^{12}$ The finding that the estimated wage effect is robust to various ways of conditioning on unobservable variables indicates that features of the teachers' choice set beyond school characteristics are not related to the wage. ${ }^{13}$

Table 5. The wage effect. The dependent variable is recently hired

\begin{tabular}{lcccccccc}
\hline & $(1)$ & $(2)$ & $(3)$ & $(4)$ & $(5)$ & $(6)$ & $(7)$ & $(8)$ \\
\hline Wage premium & $0.098^{*}$ & $0.073^{*}$ & $0.065^{*}$ & $0.064^{*}$ & $0.070^{*}$ & $0.051^{*}$ & 0.030 & 0.030 \\
& $(0.013)$ & $(0.014)$ & $(0.014)$ & $(0.015)$ & $(0.018)$ & $(0.017)$ & $(0.017)$ & $(0.015)$ \\
Permanent teacher position & & & & & & & & $-0.432^{*}$ \\
last year & - & - & - & - & - & - & - & $(0.005)$ \\
& & & & & & & & \\
Time FE * treatment school & No & Yes & Yes & Yes & Yes & Yes & Yes & Yes \\
School FE & No & No & Yes & Yes & Yes & Yes & Yes & Yes \\
Time FE * school district FE & No & No & No & Yes & Yes & Yes & Yes & Yes \\
School specific trends & No & No & No & No & Yes & Yes & Yes & Yes \\
Individual characteristics & No & No & No & No & No & Yes & Yes & Yes \\
Individual fixed effects & No & No & No & No & No & No & Yes & Yes \\
Standard error of equation & 0.361 & 0.360 & 0.356 & 0.355 & 0.354 & 0.325 & 0.268 & 0.246 \\
Observations & 401,305 & 401,305 & 401,305 & 401,305 & 401,305 & 401,152 & 401,152 & 401,152 \\
\hline
\end{tabular}

Note. The models are estimated by the linear probability model, standard errors clustered at the school level are reported in parentheses. * denotes significance at $5 \%$ level. All models include the logarithm of the number of students and the change in the logarithm of the number of students. The individual characteristics included in models (6)-(8) are a cubic in age; gender; dummy variables for marital status (unmarried, married, divorced, and widow/widower); dummy variables for children below 6 years of age, children 6-18 years of age, children above 18 years of age, and no children; dummy variable for whether the teacher is on leave; dummy variable for reduced working hours; dummy variables for years of education; dummy variable for leader position; and dummy variable for whether the teacher works in the same region as born. All coefficients for the models in columns (6) and (8) are reported in Appendix Table A1.

This estimate can be interpreted as the wage effect from the point of view of the establishment, without any regards to what type of workers that are hired. The rest of Table 5 presents estimates conditional on individual characteristics. Full models are presented in Appendix Table B1, and show that young teachers, divorced teachers, and teachers with children in school age are more likely to be recently hired than other

\footnotetext{
${ }^{12}$ The recruitment ratio of 0.212 used in this calculation is the weighted average for the treatment schools in Table 3.

${ }^{13}$ All models in Table 5 include the logarithm of the number of students and the change in the logarithm of the number of students. Excluding these two variables from the model does not alter the results. For example, the effect of the wage premium for the model in column (3) in Table 5 is reduced from 0.0647 to 0.0643 when they are excluded.
} 
teachers. The effect of age is strong and nonlinear. For example at age 30 the marginal effect is $-3.6 \mathrm{pp}$. Some of these characteristics, and in particular the age, are correlated with the wage premium simply because the share of recently hired is larger at schools with wage premium. Thus, when observable individual characteristics are included in column (6) in Table 5, the estimated wage premium effect declines (from 7.0 pp to 5.1 pp). This model estimates the probability that a conditional teacher will be recently hired, and is as such not the total effect for the establishment. The result indicates, however, that the wage effect is heterogeneous across individual characteristics, to which I will return below.

Including teacher fixed effects (column 6) and an indicator for whether the teacher had a permanent teacher position last year (column 7) reduces the wage effect even more, and in the former case it is significant only at $10 \%$ level. ${ }^{14}$ The indicator for permanent position is highly significant, clearly confirming that the mobility of teachers in permanent positions is much lower than for other teachers. ${ }^{15}$ Without tenure, the probability that the worker is forced to move is higher, and the probability that the worker is observed as recently hired is larger.

\section{Robustness analysis}

This section presents results for different samples and various model specifications.

\subsection{Control schools}

The results might be sensitive to the sample. The school districts in the counties with wage premium are relatively small. The first sub-sample used in Table 6 includes only school districts with less than 3000 students on average during the empirical period. ${ }^{16}$

\footnotetext{
${ }^{14}$ Since the dependent variable is a dummy variable, it only varies for individuals that de facto move in the sample period in the within-individual framework. The weight on mobile individuals is higher than in the other models, which should work in the direction of a larger wage effect. Excluding teachers that are not hired in the empirical period (33,947 teachers and 212,585 observations), the wage effect in a model specification similar to column (3) increases from 0.065 to 0.092 .

${ }^{15}$ Teachers with permanent position last school year change school in $4.5 \%$ of the observations, teachers with temporary teacher position last year change school in $19 \%$ of the observations, and in $9.9 \%$ of the observations the teacher did not have a teacher position last year and are thus by definition recently hired. ${ }^{16}$ This restriction excludes the two most populous school districts in the relevant counties (which both have treatment schools) and 35 school districts in other parts of the country, leaving a total of 407 school districts and 2,497 schools in the sample.
} 
The treatment schools also tend to be small. The second sub-sample excludes schools with more than 175 students on average during the empirical period. ${ }^{17}$

Most of the control schools do not have any challenges related to teacher recruitment. As such they are not ideal comparison schools in the present context. Unfortunately, information on the size of teacher shortages used to define wage premium eligibility is not available for the whole empirical period. Some official information is available from 1996, but Falch (2010) shows that the match between actual eligibility and a classification based on the public information is imperfect before 1998. The present data can be used to calculate an indicator for teacher shortages since it includes an indicator for certification. However, such an indicator will differ from the data used in the classification of eligible schools. One important difference is that the data are collected at different points in time, and that noncertified teachers can be hired on very short-term contracts. Wage premium eligibility was determined by shortages at the start of the school year in August, while the register data are collected in October. Another difference is that the official classification is based on certification for the grade the teacher is teaching. Nevertheless, the third sub-sample used in Table 6 includes only schools that have average teacher shortages above $10 \%$ during the empirical period as measured by the indicator available in the present data, which reduces the sample by almost $90 \%{ }^{18}$

The fourth sub-sample only includes the counties with treatment schools, while the last two sub-samples only include teachers that have been working at an treatment school in the empirical period. The first case includes all these teacher observations, while the last case is restricted to the treatment schools. ${ }^{19}$

\footnotetext{
${ }^{17}$ This restriction excludes the largest treatment school and 1,263 control schools, leaving a total of 424 school districts and 2,050 schools in the sample.

${ }^{18}$ The sample includes 176 school districts and 402 schools. 97 of the school districts are located outside the counties with treatment schools. None of the treatment schools are excluded from the sample, although the average teacher shortages, as measured by the available information in the present data, are below $10 \%$ in 40 out of the 158 treatment schools. Excluding these schools from the sample does not affect the results.

${ }^{19}$ Including all observations of teachers working at least one year at a treatment school implies a sample of 292 school districts and 953 schools. Using only treatment schools reduces the sample to 69 school districts and 158 schools.
} 
Table 6 shows that the estimated wage effect is stable across the sub-samples. In the model specification with only school fixed effects, the wage effect varies from 0.062 to 0.066. Including year times school district fixed effects increases the variation in the estimates to the interval 0.051 to 0.071 , and for the models including school specific trends in column (3) the estimates vary from 0.064 to 0.082 . Finally, including individual characteristics reduces the wage effect in all cases, and the estimate is in the interval 0.048 to 0.060 . The results clearly show that the main identification is the within treatment school variation.

\subsection{Omitted characteristics}

Truncation might be an issue since there is not excess demand in all observations. In 21 $\%$ of the observations of treatment schools, noncertified teachers are not employed according to the present data. There is not excess demand. If excess demand and the wage premium are positively related, truncation yields a negative bias in the wage effect. The correlation between wage premium and absence of excess demand is very low, however, indicating that the bias will be neglectable. ${ }^{20}$ Columns (1) and (2) in Table 7 restrict the sample to schools with excess demand. Contrary to expectations, the estimated wage effect is lower than for the models including all schools, but the differences are small (0.056 vs. 0.064 in the model with year times school district fixed effects). This result indicates that truncation is not an important issue.

Stochastic shocks in teacher shortages might drive the results since wage premium eligibility is related to previous shortages. Columns (3) and (4) in Table 7 address this issue by including three lags in the share of noncertified teachers at the present school, as measured by the available data starting in 1992-93. Including previous teacher shortages reduces the wage effect by about one standard error. ${ }^{21}$ Columns (5) and (6) additionally include indicators for whether teacher shortages are increasing or declining, with an additional small reduction in the wage effect (0.046 vs. 0.048). Although the

\footnotetext{
${ }^{20}$ The within-school correlation coefficient between wage premium and absence of excess demand is 0.01 for all schools and 0.03 for treatment schools, which are both insignificant.

${ }^{21}$ In the model with year times school district fixed effects, the estimate is 0.067 for the baseline model specification using the sample in column (4) in Table 7, compared to the estimate of 0.048 in the table when lags in teacher shortages are included.
} 
wage effect is smaller in these models, they are not significantly different from the estimates in Table 5, but still significantly different from zero at $5 \%$ level.

Table 6. The wage effect, different sub-samples. The dependent variable is recently hired

\begin{tabular}{|c|c|c|c|c|}
\hline & (1) & (2) & (3) & (4) \\
\hline $\begin{array}{l}\text { Only school districts with less than 3,000 students } \\
\text { on average during the empirical period }\end{array}$ & $\begin{array}{l}0.066^{*} \\
(0.015)\end{array}$ & $\begin{array}{l}0.065^{*} \\
(0.015)\end{array}$ & $\begin{array}{l}0.074^{*} \\
(0.018)\end{array}$ & $\begin{array}{l}0.055^{*} \\
(0.017)\end{array}$ \\
\hline Observations & 252,870 & 252,870 & 252,870 & 252,780 \\
\hline $\begin{array}{l}\text { Only schools with less than } 175 \text { students } \\
\text { on average during the empirical period }\end{array}$ & $\begin{array}{l}0.062^{*} \\
(0.015)\end{array}$ & $\begin{array}{l}0.071^{*} \\
(0.015)\end{array}$ & $\begin{array}{l}0.076^{*} \\
(0.018)\end{array}$ & $\begin{array}{l}0.056^{*} \\
(0.017)\end{array}$ \\
\hline Observations & 134,813 & 134,813 & 134,813 & 134,767 \\
\hline $\begin{array}{l}\text { Only schools with teacher shortages of at least } 10 \% \\
\text { on average during the empirical period }\end{array}$ & $\begin{array}{l}0.063^{*} \\
(0.014)\end{array}$ & $\begin{array}{l}0.051^{*} \\
(0.015)\end{array}$ & $\begin{array}{l}0.064^{*} \\
(0.018)\end{array}$ & $\begin{array}{l}0.052 * \\
(0.017)\end{array}$ \\
\hline Observations & 24,637 & 24,637 & 24,637 & 24,603 \\
\hline Only the counties with treatment schools & $\begin{array}{l}0.064^{*} \\
(0.014)\end{array}$ & $\begin{array}{l}0.063^{*} \\
(0.015)\end{array}$ & $\begin{array}{l}0.067 * \\
(0.018)\end{array}$ & $\begin{array}{l}0.049^{*} \\
(0.017)\end{array}$ \\
\hline Observations & 51,275 & 51,275 & 51,275 & 51,236 \\
\hline $\begin{array}{l}\text { Only teachers that have been working at an } \\
\text { treatment school in the empirical period }\end{array}$ & $\begin{array}{l}0.063^{*} \\
(0.014)\end{array}$ & $\begin{array}{l}0.062^{*} \\
(0.016)\end{array}$ & $\begin{array}{l}0.075^{*} \\
(0.021)\end{array}$ & $\begin{array}{l}0.058^{*} \\
(0.020)\end{array}$ \\
\hline Observations & 10,473 & 10,473 & 10,473 & 10,459 \\
\hline Only treatment schools & $\begin{array}{l}0.062^{*} \\
(0.015)\end{array}$ & $\begin{array}{l}0.068^{*} \\
(0.016)\end{array}$ & $\begin{array}{l}0.082^{*} \\
(0.021)\end{array}$ & $\begin{array}{l}0.065^{*} \\
(0.019)\end{array}$ \\
\hline Observations & 6,959 & 6,959 & 6,959 & 6,946 \\
\hline School fixed effects & Yes & Yes & Yes & Yes \\
\hline Time FE * school district FE & No & Yes & Yes & Yes \\
\hline School specific trends & No & No & Yes & Yes \\
\hline Individual characteristics & No & No & No & Yes \\
\hline
\end{tabular}

Note. The model specifications are equal to the models in columns (3)-(6) in Table 5. The models are estimated by the linear probability model, standard errors clustered at the school level are reported in parentheses. * denotes significance at $5 \%$ level. 
Table 7. The wage effect, sensitivity to omitted characteristics. The dependent variable is recently hired

\begin{tabular}{|c|c|c|c|c|c|c|c|c|c|c|}
\hline \multirow{2}{*}{ Sample } & (1) & (2) & (3) & (4) & (5) & (6) & (7) & (8) & \multirow{2}{*}{\multicolumn{2}{|c|}{$\begin{array}{c}(9) \quad(10) \\
\text { Only counties } \\
\text { without } \\
\text { treatment } \\
\text { schools }\end{array}$}} \\
\hline & \multicolumn{2}{|c|}{$\begin{array}{c}\text { Teacher } \\
\text { vacancies } \\
\text { present year }\end{array}$} & \multicolumn{4}{|c|}{ Time period $1995-96$ to $2000-01$} & \multicolumn{2}{|c|}{$\begin{array}{l}\text { Time period } \\
\text { 1998-99 to } \\
2000-01\end{array}$} & & \\
\hline Wage premium & $\begin{array}{l}0.059^{*} \\
(0.018)\end{array}$ & $\begin{array}{l}0.056^{*} \\
(0.019)\end{array}$ & $\begin{array}{l}0.049^{*} \\
(0.018)\end{array}$ & $\begin{array}{l}0.048^{*} \\
(0.019)\end{array}$ & $\begin{array}{l}0.047 * \\
(0.018)\end{array}$ & $\begin{array}{l}0.046^{*} \\
(0.019)\end{array}$ & $\begin{array}{l}0.049 * \\
(0.024)\end{array}$ & $\begin{array}{c}0.050 \\
(0.027)\end{array}$ & - & - \\
\hline $\begin{array}{l}\text { Fictitious wage } \\
\text { premium }\end{array}$ & - & - & - & - & - & - & - & - & $\begin{array}{l}-0.014 \\
(0.029)\end{array}$ & $\begin{array}{l}-0.0002 \\
(0.026)\end{array}$ \\
\hline $\begin{array}{l}\text { Share of vacant teacher } \\
\text { positions (t-1) }\end{array}$ & - & - & $\begin{array}{l}0.243^{*} \\
(0.051)\end{array}$ & $\begin{array}{l}0.234^{*} \\
(0.045)\end{array}$ & $\begin{array}{l}0.262 * \\
(0.076)\end{array}$ & $\begin{array}{l}0.262^{*} \\
(0.070)\end{array}$ & - & - & $\begin{array}{l}0.239 * \\
(0.046)\end{array}$ & $\begin{array}{l}0.226 * \\
(0.042)\end{array}$ \\
\hline $\begin{array}{l}\text { Share of vacant teacher } \\
\text { positions (t-2) }\end{array}$ & - & - & $\begin{array}{l}-0.033 \\
(0.024)\end{array}$ & $\begin{array}{l}-0.013 \\
(0.020)\end{array}$ & $\begin{array}{l}-0.028 \\
(0.028)\end{array}$ & $\begin{array}{l}-0.018 \\
(0.025)\end{array}$ & - & - & $\begin{array}{l}-0.044 \\
(0.030)\end{array}$ & $\begin{array}{l}-0.019 \\
(0.025)\end{array}$ \\
\hline $\begin{array}{l}\text { Share of vacant teacher } \\
\text { positions (t-3) }\end{array}$ & - & - & $\begin{array}{l}-0.045 \\
(0.032)\end{array}$ & $\begin{array}{l}-0.034 \\
(0.030)\end{array}$ & $\begin{array}{l}-0.047 \\
(0.020)\end{array}$ & $\begin{array}{l}-0.038 \\
(0.0 \mathrm{o} 3)\end{array}$ & - & - & $\begin{array}{l}-0.047 \\
(0.035)\end{array}$ & $\begin{array}{l}-0.031 \\
(0.033)\end{array}$ \\
\hline $\begin{array}{l}\text { Indicators for change in } \\
\text { teacher shortagesa }\end{array}$ & No & No & No & No & Yes & Yes & No & No & No & No \\
\hline School fixed effects & Yes & Yes & Yes & Yes & Yes & Yes & Yes & Yes & Yes & Yes \\
\hline $\begin{array}{l}\text { Time FE*school } \\
\text { district FE }\end{array}$ & No & Yes & No & Yes & No & Yes & No & Yes & No & Yes \\
\hline $\begin{array}{l}\text { Standard error of } \\
\text { equation }\end{array}$ & 0.362 & 0.361 & 0,363 & 0.362 & 0.363 & 0.362 & 0.364 & 0.363 & 0.363 & 0.362 \\
\hline Observations & 223 & 241 & & 306 & ,594 & & 165 & ,210 & 267, & 677 \\
\hline
\end{tabular}

Note. The model specifications are equal to the models in columns (3) and (4) in Table 5, except as indicated. The models are estimated by the linear probability model, standard errors clustered at the school level are reported in parentheses. * denotes significance at $5 \%$ level. a Four dummy variables are included; indicators for increasing or decreasing share of vacant teacher position from $\mathrm{t}-1$ to $\mathrm{t}$ and from $\mathrm{t}$ 2 to $\mathrm{t}-1$ (no change are the reference categories).

The bias related to potential mean reversion should be smaller in the last system for wage premium eligibility starting in the school year 1998-99. In this system eligibility is related to average teacher shortages over the last four school years, in contrast to just the previous school year as in the other systems. The models in columns (7) and (8) in Table 7 restrict the sample to the last system (the school years 1998-99 to 2000-01), which yields estimates that are very similar to the models taking lagged teacher shortages into account.

The relevance of mean reversion can also be considered by investigating patterns in the counties without wage premium schools. A falsification test is not straightforward since 
information on the size of teacher shortages used to define wage premium eligibility is not available as discussed above. Nevertheless, I have created a dummy variable equal to unity if teacher shortages at the school as measured by the present individual data were at least $20 \%$ the previous school year and average shortages during the empirical period were at least $10 \%$, and estimated similar models for a sample excluding the counties with treatment schools. This fictitious wage premium bites for 3372 teachers and 443 school observations, which are larger numbers than for the actual wage premium, but smaller in percentage terms. Columns (9) and (10) in Table 7 present the results. The estimated effect of the fictitious wage premium has the wrong sign, but is close to zero and clearly insignificant.

Employers have in general other policy instruments in addition to the wage as emphasized by Manning (2003, 2011). A wage raise can be combined with reduced hiring costs, in which case I underestimate the independent wage effect. When a school becomes eligible for the wage premium, and if hiring costs are endogenous, it is reasonable that changes in hiring costs depends on circumstances. For example, recruitment is most important with large teacher shortages, which would imply that hiring costs eventually are reduced the most when shortages are low. The hypothesis is that the estimated wage effect is increasing in teacher shortages. The same logic applies for changes in teacher demand, which can be measured by the change in the number of students since the schools have fixed catchment areas.

Figure 3 present results from a semi-parametric model specification with year times school district fixed effects included. Panel A shows that the effect of the wage premium is not systematically related to previous teacher shortages. The regression line, estimated on the point estimates in the figure using the inverse of the standard errors as weight, is only slightly upward sloping. Panel B shows that the wage effect is neither systematically related to the change in school size. ${ }^{22}$

\footnotetext{
${ }^{22}$ The average effect of the wage premium is smaller in Panel A than in Panel B in Figure 3. Since Panel A allows for different wage effects at different levels of teacher shortages, the model effectively condition on lagged shortages. In that case the wage effect is smaller as shown in Table 7.
} 
Figure 3. Non-linear wage effects. Point estimates, $95 \%$ confidence interval, and regression line

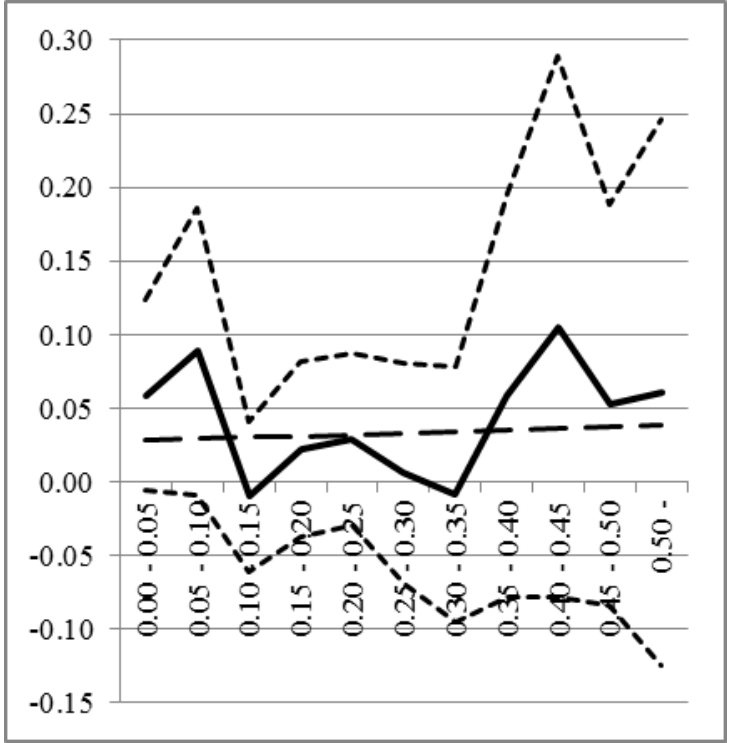

Panel A. The degree of teacher shortages

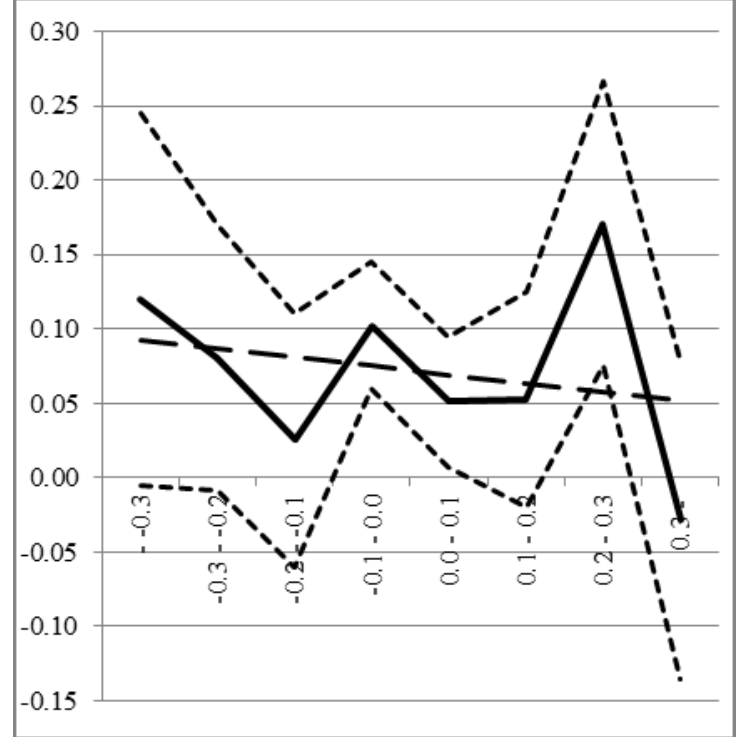

Panel B. The change in log number of students

\subsection{Individual heterogeneity}

The literature on labor supply finds that women's working hours are more responsive to the wage than men's working hours, see Killingsworth and Heckman (1986) and Pencavel (1998). In addition, Pencavel finds that the wage elasticity is highest for married women and young women. It is not straightforward to translate these supply elasticities at the market level into mobility responsiveness. One could expect that people who respond strongly in terms of hours also respond strongly in terms of mobility. The usual interpretation, however, is that women are more responsive in terms of hours since an attractive alternative for many is to stay at home. But then they are also less geographically mobile, working in the direction of less mobility responsiveness. At the firm level, Manning (2003) finds similar elasticities for both genders, while Hirsch et al. (2008) and Ransom and Oaxaca (2010) find that women’s labor supply is less elastic than men's.

Table 8 presents heterogeneous effects related to socioeconomic characteristics of the teachers. The wage effect seems to be largest for female teachers, married teachers, young teachers, and teachers without school-aged children. Except for age, however, the 
wage effects are not statistically different across groups. The table also reports results for models where the wage effect is allowed to differ for teachers with a permanent teacher position last school year. These teachers can stay in their previous position if they want. If they are observed as recently hired, they certainly prefer the present school over the previous school. I find that they seem to have a lower wage response than other teachers, but again the difference in the wage effect across the groups is not significant at $5 \%$ level.

Table 8. Heterogeneous wage effects across teachers. The dependent variable is recently hired

\begin{tabular}{|c|c|c|c|c|c|c|c|c|c|c|}
\hline Sample & Female & Male & $\begin{array}{c}\text { Married } \\
\text { each } \\
\text { year }\end{array}$ & $\begin{array}{c}\text { Not } \\
\text { married } \\
\text { each } \\
\text { year }\end{array}$ & $\begin{array}{c}\text { Average } \\
\text { age } \\
\text { below } \\
38\end{array}$ & $\begin{array}{c}\text { Average } \\
\text { age } \\
\text { above } \\
38\end{array}$ & $\begin{array}{c}\text { No } \\
\text { children } \\
\text { age } 6- \\
18 \text { any } \\
\text { year } \\
\end{array}$ & $\begin{array}{c}\text { Children } \\
\text { age 6- } \\
18 \text { at } \\
\text { least } \\
\text { one year }\end{array}$ & $\begin{array}{c}\text { Permanent } \\
\text { position } \\
\text { last year }\end{array}$ & $\begin{array}{c}\text { Not } \\
\text { permanent } \\
\text { position } \\
\text { last year }\end{array}$ \\
\hline Wage premium & $\begin{array}{l}0.067 * \\
(0.019)\end{array}$ & $\begin{array}{c}0.046 \\
(0.024)\end{array}$ & $\begin{array}{l}0.053^{*} \\
(0.018)\end{array}$ & $\begin{array}{c}0.037 \\
(0.029)\end{array}$ & $\begin{array}{l}0.114^{*} \\
(0.028)\end{array}$ & $\begin{array}{c}0.022 \\
(0.015)\end{array}$ & $\begin{array}{l}0.081 * \\
(0.024)\end{array}$ & $\begin{array}{l}0.045^{*} \\
(0.020)\end{array}$ & $\begin{array}{l}0.036^{*} \\
(0.010)\end{array}$ & $\begin{array}{c}0.060 \\
(0.035)\end{array}$ \\
\hline Schoo & Yes & Yes & Yes & Yes & Yes & Yes & Yes & Yes & Yes & $\mathrm{Ye}$ \\
\hline Time FE*school & Yes & Yes & Yes & Yes & Yes & Yes & Yes & Yes & Yes & Yes \\
\hline $\begin{array}{l}\text { Standard error of } \\
\text { equation }\end{array}$ & 0.367 & 0.326 & 0.302 & 0.424 & 0.460 & 0.276 & 0.381 & 0.325 & 0.203 & 0.476 \\
\hline Observations & 265,868 & 135,352 & 254,633 & 100,051 & 109,188 & 292,117 & 185,680 & 215,625 & 317,286 & 84,019 \\
\hline
\end{tabular}

Note. The model specification is equal to the model in column (4) in Table 5, except sample. The models are estimated by the linear probability model, standard errors clustered at the school level are reported in parentheses. * denotes significance at five $\%$ level.

\subsection{Stability and dynamic effects}

Even though the wage response depends on individual characteristics, we would expect constancy across time and regions to the extent that the composition of the teachers does not change. Columns (1) and (2) in Table 9 allow for different wage effects in the three systems of wage premium in place in the empirical period. The point estimates indicate that the effect was largest in 1996-97 to 1997-98 when the eligibility criteria was strictest and lowest in the latest system (point estimates of 0.143 and 0.051 , respectively, in the model with year times school district fixed effects), but the differences are insignificant. These results correspond to the findings for the latest system in Table 6. 
Table 9. Heterogeneous wage effects across eligibility criteria. The dependent variable is recently hired

\begin{tabular}{|c|c|c|c|c|c|c|}
\hline & (1) & $(2)$ & (3) & (4) & (5) & (6) \\
\hline Wage premium & $\begin{array}{c}0.079 * \\
(0.025)\end{array}$ & $\begin{array}{c}0.059 * \\
(0.024)\end{array}$ & $\begin{array}{c}0.086^{*} \\
(0.021)\end{array}$ & $\begin{array}{c}0.099 * \\
(0.25)\end{array}$ & $\begin{array}{c}0.071^{*} \\
(0.026)\end{array}$ & $\begin{array}{c}0.033 \\
(0.024)\end{array}$ \\
\hline \multicolumn{7}{|l|}{ Wage premium interacted with } \\
\hline School years $1996-97$ to $1997-98$ & $\begin{array}{c}0.065 \\
(0.059)\end{array}$ & $\begin{array}{c}0.094 \\
(0.058)\end{array}$ & - & - & - & - \\
\hline School years $1998-99$ to $2000-01$ & $\begin{array}{l}-0.036 \\
(0.034)\end{array}$ & $\begin{array}{c}-0.008 \\
(0.031)\end{array}$ & - & - & - & - \\
\hline County of Nordland & - & - & $\begin{array}{c}-0.051 \\
(0.030)\end{array}$ & $\begin{array}{c}-0.064 \\
(0.033)\end{array}$ & - & - \\
\hline County of Troms & - & - & $\begin{array}{l}-0.022 \\
(0.031)\end{array}$ & $\begin{array}{c}-0.025 \\
(0.036)\end{array}$ & - & - \\
\hline Not wage premium last year & - & - & - & - & $\begin{array}{c}-0.007 \\
(0.024)\end{array}$ & $\begin{array}{c}0.015 \\
(0.023)\end{array}$ \\
\hline Not wage premium next year & - & - & - & - & $\begin{array}{c}-0.002 \\
(0.024)\end{array}$ & $\begin{array}{c}0.043 \\
(0.025)\end{array}$ \\
\hline School fixed effects & Yes & Yes & Yes & Yes & Yes & Yes \\
\hline Time FE * school district FE & No & Yes & No & Yes & No & Yes \\
\hline Standard error of equation & 0.356 & 0.355 & 0.356 & 0.355 & 0.356 & 0.355 \\
\hline Observations & 401,305 & 401.305 & 401,305 & 401,305 & 401,305 & 401,305 \\
\hline
\end{tabular}

Note. The model specifications are equal to the models in columns (3)-(5) in Table 5 except as indicated. The models are estimated by the linear probability model, standard errors clustered at the school level are reported in parentheses. * denotes significance at $5 \%$ level.

Three counties were included in the system. Columns (3) and (4) in Table 9 indicate that the wage effect was largest in the northernmost county (Finnmark, effect of 0.099) and lowest in the southernmost of the relevant counties (Nordland, effect of 0.035), but again the differences are not significant.

The model formulation assumes that the wage response is static in the sense that it is only the present wage that matter for the individual decisions. The last model formulations in Table 9 allow for different wage effects the first and the last year of wage premium. If it was well known in advance which schools that would pay a wage premium, as intended, the wage effect should not be smaller the first year a school was eligible for the wage premium compared to the consecutive years. For the last year with wage premium, the effect is expected to be lower if teachers have forward looking behavior. In the model with only school fixed effects, the wage effect is clearly 
independent of the timing. In the model with year times school district fixed effects, the point estimates indicate largest effect the last year with wage premium (0.076) and lowest in the intermediate years (0.033). The differences are, however, not statistically significant.

\section{A labor supply interpretation}

The supply S faced by an establishment can be decomposed into current incumbent workers I, new hires R, and workers who want to work at the establishment but who are dismissed D.

$\mathrm{S}_{\mathrm{jt}}=\mathrm{I}_{\mathrm{jt}}+\mathrm{R}_{\mathrm{jt}}+\mathrm{D}_{\mathrm{jt}}=\left(1-\mathrm{q}_{\mathrm{jt}}\right) \mathrm{N}_{\mathrm{jt}-1}+\mathrm{R}_{\mathrm{jt}}+\mathrm{D}_{\mathrm{jt}}$,

where $\mathrm{N}$ is employment and the quit rate $\mathrm{q}$ is a flow variable. Krueger (1988), Holzer et al. (1991), and Bó et al. (2012) estimate the elasticity of job applicants with respect to the wage, which can be seen as the wage response of $(R+D)$. The labor market analyzed in the present paper is characterized by supply constrained employment, i.e., $D_{j t}=0$, which implies that $S_{j t}=N_{j t}$. Defining the inverse of the growth in supply by $\gamma_{\mathrm{jt}}=\mathrm{S}_{\mathrm{jt}-1} / \mathrm{S}_{\mathrm{jt}}$ and denoting the wage by $\mathrm{w}$, it follows from (2) that the short-run labor supply elasticity can be written as

$\varepsilon_{\mathrm{Sw}}=\frac{\partial \mathrm{S}_{\mathrm{jt}}}{\partial \ln \left(\mathrm{w}_{\mathrm{jt}}\right)} \frac{1}{\mathrm{~S}_{\mathrm{jt}}}=\left(\frac{\partial \mathrm{R}_{\mathrm{jt}}}{\partial \ln \left(\mathrm{w}_{\mathrm{jt}}\right)}-\frac{\partial \mathrm{q}_{\mathrm{jt}}}{\partial \ln \left(\mathrm{w}_{\mathrm{jt}}\right)} \mathrm{S}_{\mathrm{jt}-1}\right) \frac{1}{\mathrm{~S}_{\mathrm{jt}}}=\left(1-\left(1-\mathrm{q}_{\mathrm{jt}}\right) \gamma_{\mathrm{jt}}\right) \varepsilon_{\mathrm{Rw}}-\gamma_{\mathrm{jt}} \mathrm{q}_{\mathrm{jt}} \varepsilon_{\mathrm{qw}}$,

where $\varepsilon_{\mathrm{Rw}}$ and $\varepsilon_{\mathrm{qw}}$ are the recruitment and quit elasticities, respectively. ${ }^{23}$

In the case separations to and recruitment from non-employment are insensitive to the wage, Manning (2003) and Depew and Sorensen (2012) show that

$\varepsilon_{\mathrm{qw}}=-\frac{\left(1-\left(1-\mathrm{q}_{\mathrm{jt}}\right) \gamma_{\mathrm{jt}}\right)}{\mathrm{q}_{\mathrm{jt}}} \varepsilon_{\mathrm{Rw}}$

There is a fixed relationship between the quit and recruitment elasticities. ${ }^{24}$ Several studies assume that $\gamma_{\mathrm{jt}}=0$ and use this relationship to infer the labor supply elasticity

\footnotetext{
${ }^{23}$ Bó et al. (2012) consider a situation where a new job is created. In this case the supply elasticity is only related to recruitment. They decompose the recruitment effect into the effects on the applicant pool and the conversion rate of selected candidates into vacancies filled.
} 
based on estimates of the separation elasticity, including Ransom and Oaxaca (2010) and Falch (2011). Based on the results in the present paper and Falch (2011), it is possible to empirically consider the appropriateness of the relationship in (4).

In Falch (2011) I estimate the quit behavior of teachers in permanent positions exploiting the same wage premium system as in the present paper and find that $\varepsilon_{\mathrm{qw}}=$ 3.5. ${ }^{25}$ To consider the appropriateness of equation (5), one also needs estimates of $q$ and $\gamma$. The average quit rate at the treatment schools is about 0.18 (Falch, 2011). In the present sample the number of observations increased by $3.2 \%$ per year on average and the average growth in the number of students $2.7 \%{ }^{26}$ Thus, $\gamma$ is about 0.97 , and it follows from (4) that $\varepsilon_{\mathrm{Rw}}$ should be equal to 3.1.

The share of recruits $r=R / N$ is the theoretical counterpart to the empirical specification in this paper. Using the estimates in columns (3)-(5) in Table 5, the average recruitment rate and the average wage premium, the recruitment elasticity is about $3.5-3.8{ }^{27}$ This is reasonable close to expectations, and slightly larger than the finding in Bó et al. (2012) for new public sector positions in Mexico. Using (3), the implied supply elasticity is 1.33-1.39. Notice that this is a short-run elasticity, which makes sense in the present case since the policy intervention was short-term in nature.

\footnotetext{
${ }^{24}$ If one relaxes the assumption that separations to and recruitment from non-employment are insensitive to the wage, Manning's (2003) model implies that the relationship in equation (4) still holds in steady state under the following assumptions: (i) The elasticities for separations to employment and to nonemployment are equal, and (ii) the share of recruits from employment is insensitive to the wage. The evidence in Manning (2003), Hirsch et al. (2010), and Hotschkiss and Quispe-Agnoli (2012) indicates the estimated supply elasticity is not very sensitive to such corrections. In fact, the positive effect of the wage on the share of recruits from employment found by Manning (2003) and Hirsch et al. (2010) implies that the supply is more inelastic than what follows from equations (3) and (4).

${ }^{25}$ This result is similar to the findings by Clotfelter et al. (2008). They exploit a three-year long bonus program in North Carolina public schools serving low-income or low-performing students, and find a quit elasticity in the order of -3 to -4 .

${ }^{26}$ The large growth in the number of students is mainly due to reduced starting age of compulsory education from 7 to 6 years of age during the empirical period.

${ }^{27}$ In this calculation, it is assumed that employment $\mathrm{N}$ is independent of the wage, which is reasonable in the present case since the wage premium was paid by the state. Then the recruitment elasticity is given by $\varepsilon_{\mathrm{rw}}=(\partial \mathrm{r} / \partial \mathrm{W})(\partial \mathrm{W} / \partial \ln \mathrm{P})(1 / \mathrm{r})$, where $\mathrm{W}$ is the indictor for wage premium and $\mathrm{P}$ is the actual premium. The base wage of the teachers is available in the data. Using teachers at treatment schools, the average wage premium during the empirical period is $9.1 \%$, which amounts to $0.087 \log$ points. Regarding the recruitment rate, the weighted average of 0.212 for the treatment schools in Table 3 is used.
} 
This almost identical to the findings in Falch (2010), where the same experiment is analyzed for the period 1995-96 to 2000-01 using school level data on employment. ${ }^{28}$

However, I find that the wage effect to some extent depends on individual characteristics, and not always in the same way for the quit and recruitment decisions. Results for quit behavior (Falch, 2011) and recruitment behavior (Table 8) are summarized in Table 10. Male teachers and old teachers seem to respond stronger to the wage than women and young teachers with regard to quits, while the opposite seems to be the case with regard to recruitment. The age effect might differ because the retirement decision may be important for observed quits, while observed recruitment behavior might be driven by teachers without current permanent position. Thus, even though the quit and recruitment elasticities seem to be similar for the particular labor market considered, they clearly differ for different age groups in this market.

Table 10. Heterogeneous wage effects on recruitment and quit

\begin{tabular}{|c|c|c|c|c|c|c|c|c|}
\hline & Female & Male & $\begin{array}{c}\text { Married } \\
\text { each year }\end{array}$ & $\begin{array}{c}\text { Not } \\
\text { married } \\
\text { each year }\end{array}$ & $\begin{array}{c}\text { Average } \\
\text { age below } \\
38\end{array}$ & $\begin{array}{c}\text { Average } \\
\text { age above } \\
38\end{array}$ & $\begin{array}{c}\text { No } \\
\text { children } \\
\text { age 6-18 } \\
\text { any year }\end{array}$ & $\begin{array}{c}\text { Children } \\
\text { age } 6-18 \\
\text { at least } \\
\text { one year }\end{array}$ \\
\hline $\begin{array}{l}\text { Wage effect on } \\
\text { recruitment }\end{array}$ & $\begin{array}{l}0.067 * \\
(0.019)\end{array}$ & $\begin{array}{c}0.046 \\
(0.024)\end{array}$ & $\begin{array}{l}0.053^{*} \\
(0.018)\end{array}$ & $\begin{array}{c}0.037 \\
(0.029)\end{array}$ & $\begin{array}{l}0.114^{*} \\
(0.028)\end{array}$ & $\begin{array}{c}0.022 \\
(0.015)\end{array}$ & $\begin{array}{l}0.081^{*} \\
(0.024)\end{array}$ & $\begin{array}{l}0.045^{*} \\
(0.020)\end{array}$ \\
\hline $\begin{array}{l}\text { Wage effect on } \\
\text { quit }\end{array}$ & $\begin{array}{l}-0.040 \\
(0.026)\end{array}$ & $\begin{array}{l}-0.110^{*} \\
(0.034)\end{array}$ & $\begin{array}{l}-0.092 * \\
(0.026)\end{array}$ & $\begin{array}{l}-0.028 \\
(0.031)\end{array}$ & $\begin{array}{l}-0.045 \\
(0.042)\end{array}$ & $\begin{array}{l}-0.073 * \\
(0.023)\end{array}$ & $\begin{array}{l}-0.086 * \\
(0.037)\end{array}$ & $\begin{array}{l}-0.067 * \\
(0.028)\end{array}$ \\
\hline
\end{tabular}

Note. Results as reported in Falch (2011) Table 3 and Table 8 above.

\section{Conclusion}

Causal evidence on wage effects is hard to establish since a myriad of factors in general influence observed wages. This paper exploits centralized determined wage variation for teachers in Norway in a difference-in-differences framework, identifying the wage effect on schools that have excess demand for teachers. The wage premium of about 10 $\%$ is found to increase recruitment by about $30 \%$, which implies a short-run recruitment elasticity of about 3.5. The result is robust to several robustness checks, including

\footnotetext{
${ }^{28}$ Matsudaira (2010) exploits a very different quasi-natural experiment, namely a legislation increasing the minimum number of nurses in the long-term care industry in California. He find evidence of a very elastic supply curve and cannot reject the neoclassical model.
} 
changes in sample. The elasticity is similar in absolute terms to previous findings for separations. The wage responsiveness is significant, but not massive. Interpreted in a labor supply framework, the results imply a short-run labor supply elasticity of about 1.4 .

The empirical results are in accordance with economic theory, which predicts that in steady state the separation and recruitment elasticities with respect to the wage are equal in absolute terms. However, there is some evidence that the wage effect depends on individual characteristics. In particular, this paper indicates that recruitment is more responsive to the wage for young teachers than for old teachers, while the opposite seems to be the case for quit decisions.

The estimated elasticities in the present paper are partial since schools and school districts cannot influence the wage level. The general equilibrium effects are smaller in the case of wage spillovers as found by Staiger et al. (2010). When frictions are present in the labor market, as this study suggests, some wage-setting power lies in the hands of the establishments. The possible exploration of monopsony power in the short run must be balanced against long-run considerations when workers can more fully react to wage differentials. 


\section{References}

Bó, E. D., F. Finan, and M. Rossi. 2012. "Strengthening State Capabilities: The Role of Financial Incentives in the Call to Publiv Services.” NBER Working Paper 18156.

Bonesrønning, H., T. Falch, and B. Strøm. 2005. "Teacher Sorting, Teacher Quality, and Student Composition.” European Economic Review 49, 457-483.

Boyd, D., H. Lankford, S. Loeb, and J. Wyckoff. 2012. “Analyzing the Determinants of the Matching of Public School Teachers to Jobs: Disentangling the preferences of teachers and employers.” Journal of Labor Economics, forthcoming.

Brown, A. J. G., C. Merkl, and D. J. Snower, 2012. “An Incentive Theory of Matching.” Working Paper.

Clotfelter, C., E. Glennie, H. Ladd, and J. Vigdor. 2008. "Would Higher Salaries Keep Teachers in High-Poverty Schools? Evidence from a Policy Intervention in North Carolina.” Journal of Public Economics 92, 1352-1370.

Depew, B., and T. Sorensen. 2012. "The Elasticity of Labor Supply to the Firm Over the Business Cycle.” IRLE Working Paper 2012-3, UC Los Angeles.

Falch, T. 2010. “The Elasticity of Labor Supply at the Establishment Level.” Journal of Labor Economics 28, 237-266.

Falch, T. 2011. "Teacher mobility responses to wage changes: Evidence from a quasinatural experiment.” American Economic Review 101, 460-465.

Hirsch, B., T. Schank and C. Schnabel. 2010. "Differences in Labor Supply to Monopsonistic Firms and the Gender Pay Gap: An Empirical Analysis Using Linked Employer-Employee Data from Germany.” Journal of Labor Economics 28, 291-330.

Holzer, H. J., L. F. Katz and A. B. Krueger. 1991. “Job Queues and Wages.” The Quarterly Journal of Economics 106, 739-768.

Hotchkiss, J. L., and M. Quispe-Agnoli. 2012. "Employer Monopsony Power in the Labor Market for Undocumented Workers." Federal Reserve Bank of Atlanta Working Paper 2009-14d.

Killingsworth, M. R. and J. J. Hekcman. 1986. “Female Labor Supply: A Survey.” In O. Ashenfelter and R. Layard (eds) Handbook of Labor Economics, vol. 1., Elsevier Science Publishers BV, Amsterdam.

Krueger, A. B. 1988. “The Determinants of Queues for Federal Jobs.” Industrial and Labor Relations Review 41, 567-581. 
Manning, A. 2003. Monopsony in Motion. Imperfect Competition in Labor Markets. Princeton University Press.

Manning, A. 2011. "Imperfect Competition in the Labor Market.” In O. Ashenfelter and D. Card (eds) Handbook of Labor Economics, vol. 4B., Elsevier Science Publishers BV, Amsterdam.

Matsudaira, J. D. 2010. "Monopsony in the Low-Wage Labor Market? Evidence from Minimum Nurse Staffing Regulations.” Working Paper.

Pencavel, J. 1998. “The Market Work Behavior and Wages of Women: 1975-94.” Journal of Human Resources 33,772-804.

Ransom, M. R., and D. P. Sims. 2010. "New Market Power Models and Sex Differences in Pay.” Journal of Labor Economics 28, 267-290.

Ransom, M. R., and R. L. Oaxaca. 2010. “Estimating the Firm’s Labor Supply Curve in a "New Monopsony” Framework: School Teachers in Missouri." Journal of Labor Economics 28, 331-365.

Rogerson, R., R. Shimer, and R. Wright. 2005. "Search-Theoretic Models of the Labor Market: A Survey.” Journal of Economic Literature 43, 959-988. 
Appendix Table A1. Full models

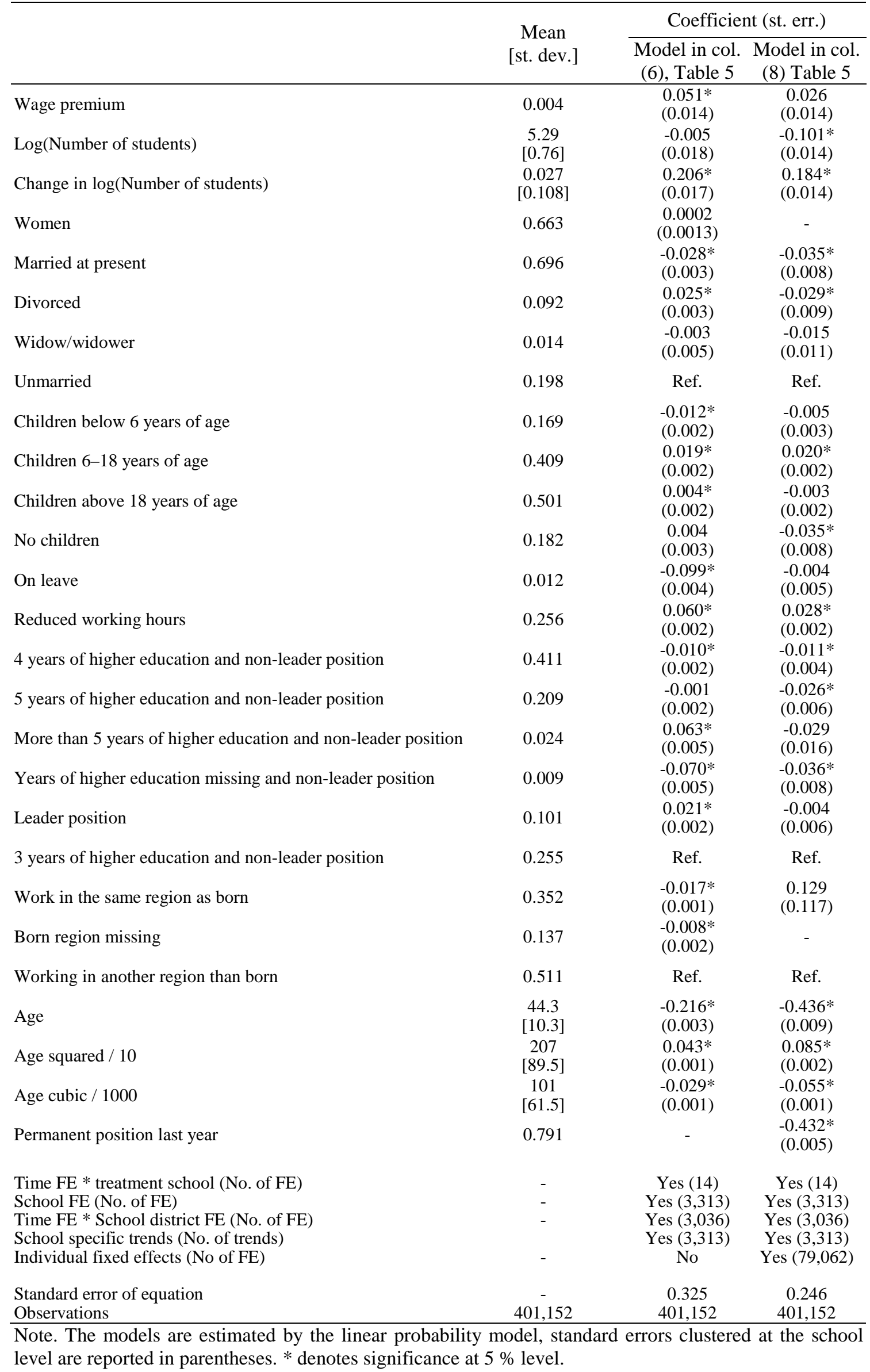

